\title{
MEMBONGKAR KESALAHAN POLA ASUH ANAK DALAM MITOS-MITOS DI INDONESIA
}

\author{
Oleh Else Liliani \\ FBS Universitas Negeri Yogyakarta
}

\begin{abstract}
This article is about a research conducted to clarify (1) the structural characteristics of myths in Indonesia, (2) the child-rearing patterns found in the myths, (3) errors in child rearing reflected in the myths, and (4) the relevance of the myths and child-rearing patterns to the contemporary realities in Indonesia.

With the myths in Indonesia as the objects of the research, by means of purposive random sampling, 15 myths were selected for study. The data were obtained by means of a read-and-write technique and they were analyzed by (1) reading the myths and seeking the story units and (2) organizing the story units in accordance with the story development. The validity of the data was tested through semantic validity and their reliability was tested by repeated readings.

The research results indicate that (1) the structural characteristics of myths in Indonesia are, among others, that (a) in child rearing the mother figures have the characteristic of being gentle and a part of the father figures have the characteristic of being stern, (b) most of the myths have the social background of the lower class and the economic background of the poor, (c) the child figures possess a sufficiently good need of achievement and a sufficiently good emotional quotient, (d) the child figures experience considerable social conflict, (e) the parent figures play minimum parts in the story, and (f) most of the child figures receive punishments and experience dehumanization, (2) the patterns of child rearing are found to have enough variety but they are mostly dominated by authoritarian, neglectful, and indulgent ones, (3) the errors of child rearing reflected are, among others, the minimum roles of parents and a disproportional child-rearing pattern of giving more punishments than rewards, and (4) the myths put under study have relevance to today's matters related to child rearing such as education, health, and child abuse.
\end{abstract}

Keywords: myths, structure and pattern of child rearing

\section{A. PENDAhuluan}

Mitos tak lain merupakan sebuah upaya untuk mengatasi dan memecahkan masalah kehidupan atau berbagai kontradiksi yang tidak dapat dipahami oleh nalar manusia (Ahimsa-Putra, 1998:45). Mitos-mitos itu diciptakan sebagai sebuah sistem simbol yang darinyalah maka manusia akan memandang, menafsirkan, dan memahami realitas empiris sehari-hari sehingga realitas yang tak beraturan tampak beraturan, tidak mengandung kontradiksi atau hal-hal yang tidak masuk akal.

Mitos-mitos yang ada di Indonesia ternyata memiliki struktur cerita yang terpola dan menarik untuk dikaji, terutama dalam hal pola pengasuhan anak. Pemikiran tentang bagaimana pola pengasuhan anak yang benar itu tentu saja masih memiliki nilai-nilai relevansi terhadap kehidupan masa kini. Hasil kajian terhadap struktur mitos di Indonesia 
setidaknya akan mengungkapkan pola pengasuhan anak yang diwariskan oleh para leluhur bangsa Indonesia ini. Serta, bagaimana akses negatif yang bisa muncul dari kesalahan pola asuh anak.

Untuk membongkar kesalahan pola asuh anak yang bisa menyebabkan dehumanisasi itu, maka perlu dilakukan kajian terhadap mitos-mitos yang ada di Indonesia. Mitos-mitos yang ada di setiap daerah di Indonesia perlu diambil sampelnya, dan dikaji secara struktural untuk menemukan struktur dan pola-pola pengasuhan anak yang ada. Hasil kajian terhadap mitos-mitos itu dapat dimanfaatkan sebagai bahan pemikiran, perbaikan, dan penentuan kebijakan terkait dengan masalah pola pengasuhan anak.

Tujuan penelitian ini adalah untuk (1) menjelaskan karakteristik struktur cerita mitos di Indonesia; (2) menjelaskan pola-pola pengasuhan anak yang terdapat dalam cerita mitos di Indonesia; (3) menjelaskan kesalahan pola asuh yang terefleksi dalam mitos di Indonesia; dan (4) menjelaskan relevansi mitos dan pola pengasuhan anak dengan realitas mutakhir di Indonesia

Sebagai sebuah teks, makna dari sebuah kebudayaan dengan demikian dapat diketahui latar pemikirannya, di mana makna kebudayaan diperoleh dari mekanisme artikulasinya (Pettit dalam Ahimsa-Putra, 1999:31). Sebuah struktur tidak berhenti hanya pada struktur permukaan. Struktur permukaan (surface structure) hanyalah kulit dari struktur dalam (deep structure). Struktur dalam perlu diketahui untuk mengetahui "apa di balik" suatu tindak kebudayaan. (Ahimsa-Putra, 1999: 67-71; Saifuddin, 2005:192).

Sebagai sebuah hasil nalar manusia dan mempunyai strukturnya, maka mitos dapat dianalisis dari satuan-satuan terkecil yang membentuknya (mytheme). Mytheme adalah kalimat atau kata-kata yang menunjukkan adanya relasi-relasi tertentu atau yang mempunyai makna tertentu, dan kadang bersifa biner. Langkah selanjutnya adalah menyusun mytheme-mytheme secara sintagmatik dan paradigmatik, secara sinkronis dan diakronis agar pesan yang ada dapat ditangkap lebih mudah dan menunjukkan adanya "vareasivareasi dari sebuah tema" (Ahimsa-Putra, 1998:49-50; Endraswara, 2004:113).

Sastra merupakan media yang sangat efektif untuk mendidik anak-anak. Apa sebab? Karena, dalam sastra terdapat nilai-nilai yang bermanfaat bagi perkembangan anak-anak (Tarigan, 1995:6-12) karena memiliki nilai instrinsik dan ekstrinsik bagi perkembangan anak. Salah satu jenis cerita yang bisaa dikenalkan kepada anak-anak adalah mitos (mythe). Menurut Lukens (2003:26), mitos merupakan sesuatu yang diyakini bangsa atau mayarakat tertentu yang pada intinya menghadirkan kekuatan-kekuatan supranatural. Mitos juga sering dikaitkan dengan cerita tentang berbagai peristiwa dan kekuatan, asal-usul tempat, tingkah laku manusia. Menurut Saxby (dalam Nurgiyantoro, 2005:173), kenyataan bahwa mitos muncul pada setiap mayarakat atau kultur berkaitan dengan kebutuhan mayarakat yang bersangkutan untuk menjawab bebagai persoalan yang tidak diketahuinya.

Rahman (2005:20-27) dalam bukunya Tahapan Mendidik Anak, pola pengasuhan anak yang ideal antara lain tampak dengan pembekalan yang dilakukan oleh para orang tua kepada anaknya, yang tidak saja meliputi kemampuan materi. Bekal-bekal yang diberikan kepada anak sebaiknya merupakan balancing (keseimbangan) antara material dan immaterial yang meliputi kecerdasan emosi, intelektual, dan spiritual. Kecerdasankecerdasan itu perlu diturunkan kepada anak dalam rangka mempersiapkan anak sebagai seorang individu yang memiliki integritas kepribadian dan moral yang baik.

Menurut Diana Baumrind, seorang pakar psikolog anak, ada empat jenis pola pengasuhan anak, yaitu otoriter, neglectful, indulgent, dan authoritative. Pola otoriter adalah pengasuhan yang kaku, diktator dan memaksa anak untuk selalu mengikuti perintah orang tua tanpa banyak alasan. Pola neglectful adalah pola pengasuhan dimana orang tua tidak mau terlibat dan tidak mau pula pusing-pusing 
memedulikan kehidupan anaknya. Pola indulgent cenderung membiarkan anaknya melakukan apa saja sesuai dengan keinginan mereka, sedangkan pola autoritatif mendorong anak untuk mandiri, tapi orang tua tetap menetapkan batas dan kontrol. Orang tua biasanya bersikap hangat, dan penuh welas asih kepada anak, bisa menerima alasan dari semua tindakan anak, mendukung tindakan anak yang konstruktif.

\section{B. METODE PENELITIAN}

Objek penelitian ini adalah 15 mitos yang berasal dari berbagai daerah di Indonesia, antara lain Doyan Nada dan Cilinaya (NTB), Gunung Batu Hapu dan Semangka Emas (Kalimantan), Tangkuban Perahu (Jawa), Munculnya Burung Kowa dan Legenda Ile Mauraja (NTT), Asal Mula Kali Maru dan Asal Mula Batu Emas (Irian Jaya), Asal Mula Burung Ntaapo-apo, Legenda Batu Bagga, dan Asal Mula Pohon Sagu dan Pohon Palem (Sulawesi), Pulau Sikintan dan Padi Muda (Sumatera), dan Manik Angkeran (Bali). Data diambil dengan menggunakan teknik baca dan catat. Data dianalisis dengan cara: (1) membaca mitos dan mencari mitem atau satuan cerita dan (2) menyusun mitem sesuai dengan perkembangan cerita. Validitas data diuji melalui validitas semantik dan reliabilitasnya diuji dengan membacanya secara berulangulang.

\section{HAS I L PENELITIAN DAN PEMBAHASAN}

1. Karakteristik Struktur Cerita Mitos di Indonesia

Mitos-mitos yang dikaji dalam penelitian ini menunjukkan adanya suatu kecenderungan karakter, di antaranya terlihat dalam profil orang tua dalam mendidik tokoh anak, karakteristik tokoh anak, latar belakang keluarga, dan penyusunan mitem-mitem berdasarkan episode perkembangan cerita. Semua tokoh orang tua dalam mitos-mitos di Indonesia sebenarnya menunjukkan sikap kasih sayang dan perhatian kepada tokoh anak-anak. Namun, ada karakter yang cukup berbeda antara tokoh ayah dan ibu dalam mendidik. Semua tokoh ibu memiliki karakter lemah lembut dalam mendidik anak. Ini berbeda dengan karakter ayah yang memiliki karakter keras (cenderung kasar) dalam mendidik anak dan memimpin keluarga. Tokoh ayah berkarakter keras dapat ditemui dalam mitos berjudul Doyan Nada dari Nusa Tenggara Barat dan Asal Mula Pohon Sagu dan Pohon Palem dari Sulawesi.

Cerita dalam mitos di Indonesia cenderung mengambil latar belakang keluarga yang ekonominya miskin, kecuali Manik Angkeran, Cilinaya, Semangka Emas, dan Doyan Nada. Mitos Doyan Nada mempunyai latar belakang keluarga yang kaya. Keluarga Doyan Nada adalah pemimpin suku yang dihormati oleh masyarakat. Demikian juga dengan keluarga Manik Angkeran yang pendeta, kaya, dan dihormati oleh banyak orang. Cilinaya berangkat dari keluarga kaya (ayah Cilinaya adalah seorang raja) dan tokoh anak dalam cerita mitos Semangka Emas memiliki orang tua yang kaya raya. Latar sosial dalam cerita mitos yang dikaji sebagian besar mengambil setting kelas sosial yang rendah atau masyarakat biasa. Hanya beberapa saja, seperti Cilinaya, Manik Angkeran, Doyan Nada, dan Semangka Emas saja yang menunjukkan bahwa tokoh anak dibesarkan dalam keluarga yang terpandang (kelas sosialnya tinggi). 11 mitos lainnya berangkat dari kelas sosial yang rendah.

Tokoh anak dalam mitos-mitos yang dikaji sebenarnya menunjukkan adanya karakter yang positif, yakni memiliki kemauan yang kuat dalam meraih sesuatu dan memiliki kemampuan manajemen emosi yang baik dalam mengatasi persoalan-persoalan yang mereka alami. Akhirnya, yang muncul adalah sifat-sifat tekun dan sabar dalam menghadapi persoalan. Namun, tidak semua tokoh anak memiliki kecerdasan emosi. Hanya sekitar $53,3 \%$ tokoh anak yang memilikinya dan 46,7\% nya tidak memiliki kecerdasan emosi. Tokoh yang memiliki kecerdasan emosi, misalnya, ada dalam cerita mitos Semangka Emas. 
Pengasuhan anak secara langsung oleh orang tua berdampak positif. Dalam episode tumbuh-kembang tokoh, tokoh-tokoh anak dalam 15 mitos memiliki karakter positif sebesar $80 \%$. Hanya sekitar $20 \%$ saja yang tak memiliki karakter baik. Karakter anak yang kurang baik dapat ditemui dalam mitos Tangkuban Perahu, Asal Mula Burung Ntaapapo, dan Manik Angkeran. Tokoh-tokoh anak dalam 12 mitos selain ketiga mitos di atas (Asal Mula Burung Ntaapo-apo, Manik Angkeran, dan Tangkuban Perahu), memiliki karakter yang positif. Tokoh Cilinaya dalam cerita mitos Cilinaya, misalnya dapat menentukan mana yang baik dan tidak bagi dirinya.

Pada episode konflik tokoh anak inilah, eksistensi dan potensi seorang anak semakin terlihat. Tokoh-tokoh anak dalam mitos lebih banyak mengalami konflik sosial $(73,3 \%)$ dan $26,7 \%$ di antaranya mengalami konflik ekonomi. Konflik sosial yang dimaksud dalam penelitian ini adalah konflik yang dialami oleh anak ketika dia mencoba berinteraksi dengan orang-orang di sekelilingnya, seperti orang tua, keluarga, atau masyarakat. Konflik sosial yang dialami oleh tokoh anak antara lain berupa kemampuan anak untuk mengkomunikasikan pikiran atau perasaannya kepada tokoh lain, keterlibatan dan kemampuan tokoh anak dalam mengatasi persoalan dengan lingkungan sekitar, kesadaran sosial, dan kepatuhan kepada hukum-pranata. Asal Mula Batu Emas, misalnya. Persoalan dalam cerita mitos ini bermula dari persoalan kawin sedarah antara saudara kandung, yakni Nanimbia dan Nebea. Mereka menyalahi aturan yang sudah ditentukan oleh orang tua dan masyarakat mereka. Manik Angkeran dalam cerita mitos Manik Angkeran tidak bisa melepaskan diri dari jerat lingkungan tempatnya bermain yang gemar berjudi. Permasalahan dalam cerita mitos Munculnya Burung Kowa muncul karena kekurangsadaran tokoh kakak untuk menghidupi adik-adiknya, Mau dan Bete. Persoalan komunikasi, misalnya, muncul dalam cerita Asal Mula Pohon Palem dan Pohon Sagu. Tokoh ayah dan ibu dalam mitos tersebut mengalami kesulitan komunikasi.
Tokoh ayah dan ibu sama-sama kurang terbuka, sedangkan tokoh anak sendiri akhirnya mengalami kesulitan komunikasi dengan orang tuanya.

Episode akhir konflik menunjukkan bahwa hampir $80 \%$ tokoh anak mendapatkan hukuman dari orang terdekat mereka $(53,3 \%)$. $20 \%$ hukuman muncul dari tokoh selain orang tua, misalnya dari tokoh dewa-dewi. Hanya $26,7 \%$ orang tua yang tidak menghukum anak mereka. Tokoh anak dalam cerita mitos Padi Muda, Cilinaya, Semangka Emas, dan Munculnya Burung Kowa tidak mendapat hukuman dari orang tua mereka. Temuan menarik lainnya dalam penelitian ini adalah sangat kecilnya jumlah orang tua yang mendapat hukuman, yakni dalam cerita mitos Asal Mula Pohon Sagu dan Pohon Palem. Tokoh orang tua (ayah dan ibu) mengalami dehumanisasi dengan menjadi pohon palem dan pohon sagu.

Temuan menarik lainnya dalam penelitian ini adalah sangat kecilnya jumlah orang tua yang mendapat hukuman, yakni dalam cerita mitos Asal Mula Pohon Sagu dan Pohon Palem. Tokoh orang tua (ayah dan ibu) mengalami dehumanisasi dengan menjadi pohon palem dan pohon sagu. Tafsir dari cerita mitos ini bahwa ketidakmampuan mereka untuk berkomunikasi secara jujur dan terbuka menyebabkan mereka kehilangan harkat martabatnya sebagai manusia. Selain itu, sikap kedua orang tua dalam mitos tersebut membawa dampak yang kurang baik bagi anakanak mereka. Anak akhirnya menjadi bingung dengan sikap di antara mereka berdua.

\section{Pola Pengasuhan Anak yang Terdapat dalam Mitos di Indonesia}

Menurut Diana Baumrind, seorang pakar psikolog anak, ada empat jenis pola pengasuhan anak, yaitu otoriter, neglectful, indulgent, dan authoritative. Pola otoriter adalah pengasuhan yang kaku, diktator dan memaksa anak untuk selalu mengikuti perintah orang tua tanpa banyak alasan. Pola neglectful adalah pola pengasuhan dimana orang tua tidak mau terlibat dan tidak mau pula pusing-pusing 
memedulikan kehidupan anaknya. Pola indulgent cenderung membiarkan anaknya melakukan apa saja sesuai dengan keinginan mereka, sedangkan pola autoritatif mendorong anak untuk mandiri, tapi orang tua tetap menetapkan batas dan kontrol. Orang tua biasanya bersikap hangat, dan penuh welas asih kepada anak, bisa menerima alasan dari semua tindakan anak, mendukung tindakan anak yang konstruktif.

Hasil penelitian menunjukkan bahwa pola asuh anak yang otoriter ditemukan dalam lima cerita mitos, yakni Semangka Emas, Cilinaya, Tangkuban Perahu, Asal Mula Pohon Palem dan Pohon Sagu, dan Doyan Nada. Pola pengasuhan anak yang neglectful ada dalam cerita mitos Asal Mula Batu Emas, Munculnya Burung Kowa, Asal Mula Burung Ntaapo-apo, dan Padi Muda. Pola pengasuhan indulgent ada dalam cerita mitos Manik Angkeran, sedangkan pola autoritatif ada dalam cerita mitos Legenda Ile Mauraja, Gunung Batu Hapu, Legenda Batu Bagga, Asal Mula Kali Maru, dan Pulau Sikintan.

Pola pengasuhan anak yang bersifat otoriter antara lain muncul dalam cerita mitos Tangkuban Perahu. Dalam cerita mitos ini, tokoh ibu (Dayang Sumbi) langsung menghukum Sangkuriang karena telah membunuh Tumang (anjing kesayangan tokoh ibu, "ayah" si Sangkuriang) tanpa menanyakan sebabnya. Dayang Sumbi kemudian langsung menghukum Sangkuriang dengan memukulkan centong (sendok nasi) ke dahinya Sangkuriang sehingga menyebabkan dahinya luka dan berdarah. Sangkuriang pun kemudian diusir pergi oleh ibunya.

Pola pengasuhan neglectful antara lain tampak pada cerita mitos Munculnya Burung Kowa. Dalam mitos ini, peran orang tua digantikan oleh tokoh kakak dari Mau dan Bete. Tokoh Kakak dalam mitos ini digambarkan tak mau mengurusi adik-adik yang dititipkan oleh orangtua kepadanya. Karena lalai mengurusi semua kebutuhannya, tokoh Mau dan Bete akhirnya terlantar dan menjadi burung kowa.

Pola pengasuhan indulgent, misalnya, ditunjukkan dalam cerita Manik Angkeran.
Dalam cerita mitos ini, tokoh orang tua tidak memiliki posisi tawar-menawar kepada anak mereka, Manik Angkeran. Orang tua Manik Angkeran cenderung menuruti semua kemauan Manik Angkeran, termasuk ketika Manik Angkeran meminta uang untuk berjudi dan membayar hutang-hutang karena kegemarannya main judi.

Sikap indulgent lebih banyak muncul pada tokoh ibu. Tokoh ibu hampir tak memiliki kekuatan untuk menolak atau tidak menuruti kemauan Manik Angkeran, termasuk ketika Manik Angkeran memaksa dan mengancam ibunya untuk menceritakan rahasia dari mana tokoh ayah mendapatkan harta dan emas yang begitu banyak. Pola pengasuhan anak yang autoritatif, misalnya, muncul pada cerita mitos Padi Muda. Dalam cerita mitos ini, tokoh ibu bisa berperan sebagai orang tua yang bersikap hangat dan welas asih kepada anaknya. Tokoh ibu bisa meredam sementara keinginan anaknya yang sak dhet sak nyet (bhs Jawa: keinginan yang harus dipenuhi saat itu juga).

\section{Kesalahan Pola Asuh yang Terefleksi dalam Mitos di Indonesia}

Melihat minimnya peran orang tua dan banyaknya jumlah sanksi atau hukuman yang ditimpakan pada anak merupakan salah satu bentuk kesalahan pola asuh anak. Ketiadaan peran orang tua sebagai teman dan sahabat anak bisa jadi memperparah kondisi anak, dan justru tidak membantu menyelesaikan masalah mereka.

Tokoh orang tua dalam cerita mitos yang dikaji menunjukkan posisi mereka yang dominan dalam kehidupan anak mereka. Tokoh orang tua lebih banyak memberikan hukuman daripada rewards atau upaya-upaya pemberian pengertian kepada tokoh anak. Selain itu, tokoh orang tua banyak melakukan kekerasan verbal terhadap anak.

Jika dikaitkan dengan pola asuh anak yang ada dalam mitos-mitos yang dikaji, maka didapat beberapa catatan mengenai kesalahan atau kekurangan dalam pola-pola pengasuhan yang diterapkan oleh tokoh orang tua terhadap tokoh anak. Cerita mitos Padi Muda, misalnya, 
tidak juga memberikan hasil yang positif dengan model pengasuhan yang menunjukkan ciri autoritatif ini. Tokoh anak dalam mitos ini menjadi burung pipit. Mengapa? Karena, tokoh ibu sering kali ingkar untuk memenuhi keinginan anaknya untuk makan padi muda. Berkali-kali, setiap ibu memberikan pengertian kepada anak, tokoh anak mencoba memahami. Namun, ketika tokoh ibu alpa terhadap janjinya untuk yang ke sekian kali, tokoh anak itu menjadi burung pipit. Tokoh ibu, di akhir cerita, digambarkan mengalami penyesalan karena telah lupa dan mengabaikan janjinya kepada anaknya.

Dari mitos Padi Muda, dapat diambil pelajaran bahwa sikap yang autoritative harus diimbang dengan kemampuan orang tua untuk memenuhi janji atau mengimplementasikan alasan-alasan yang dikemukakan kepada anak dalam kehidupan nyata. Sikap indulgent (tak memiliki posisi tawar) dalam cerita mitos Manik Angkeran perlu menjadi catatan tersendiri bagi para ibu dalam mendidik anak. Ibu biasanya memiliki karakter welas asih dan lemah-lembut dalam mendidik anak. Namun, orang tua harus memiliki sikap dalam menentukan pada saat atau kondisi seperti apa kemauan anak dituruti, dan konsekuensi atau langkah apa yang kemudian dapat dilakukan setelah kemauan itu dituruti. Cerita mitos Munculnya Burung Kowa menunjukkan bahwa sikap cuek atau tak mau tahu dengan urusan anak dan lebih memperhatikan kebutuhannya sendiri bukanlah contoh pola pengasuhan anak yang benar. Cerita mitos Tangkuban Perahu memberikan pelajaran berharga dalam mendidik anak. Hukuman fisik yang diberikan kepada tokoh anak bukan cara penyelesaian yang bagus, terlebih jika anak menjadi terluka dan cacat.

Dari pola-pola asuh yang ditemukan dalam kajian mitos di atas, dapat ditarik kesimpulan bahwa pola-pola pengasuhan yang cenderung otoriter, neglectful, dan indulgent akan sulit untuk menghasilkan pribadi-pribadi yang matang dan bertanggung jawab. Karakter anak yang positif, kemandirian serta potensi anak yang cukup besar tidak akan terasah atau berkembang dengan cara-cara pengasuhan seperti ini. Pola pengasuhan anak yang cenderung autoritatif pun harus diimbangi dengan kemampuan orang tua untuk bersikap konsisten dalam mengimplementasikan dan mewujudkan sikap-sikap atau perilaku yang ditanamkan kepada anak-anaknya.

Mitos-mitos yang dikaji memang menunjukkan adanya kesalahan pola asuh di dalamnya. Namun, apakah memang tidak ada contoh-contoh pengasuhan anak yang berhasil diterapkan dan bisa menjadi pelajaran dalam mitos-mitos Indonesia lainnya? Untuk mencari jawaban ini, ternyata tidak begitu mudah. Karena, dari mitos-mitos yang dibaca, peneliti baru menemukan contoh mitos yang di dalamnya menceritakan keberhasilan orang tua dalam mengasuh anaknya. Cerita mitos yang dimaksud adalah Si Kepar dan Banta Barensyah dari Aceh dan Rambun Pamenan dari Sumatera Barat.

Banta Barensyah dan Si Kepar menunjukkan pola yang hampir sama. Kedua tokoh anak dalam mitos itu diasuh secara single parent oleh tokoh ibu yang menjanda dan memiliki karakter welas asih, sabar dalam mendidik tokoh anak, serta bersifat terbuka dalam mengasuh anak. Tokoh ibu tak segan untuk membuka kesempatan dialog dengan anaknya. Tokoh anak dalam kedua cerita ini juga memiliki karakter yang positif: cerdas, jujur, dan berbakti kepada orang tua. Bahkan, dengan kecerdasannya ini, tokoh Kepar ini berhasil menyatukan kembali kedua orang tuanya yang telah berpisah. Tokoh anak dalam cerita Banta Barensyah berhasil membawa tokoh ibunya yang janda dalam kehidupan yang lebih layak dengan ketekunannya, kesabaran, dan sikap yang berbakti kepada orang tua.

Dalam cerita Rambun Pamenan, tokoh anak juga diasuh secara single parent oleh ibunya. Karakter tokoh Rambun juga hampir mirip dengan Si Kepar dan Banta Barensyah. Tokoh Rambun juga merupakan tokoh anak yang berbakti kepada orang tuanya. Ibu Rambun berhasil mendidik anaknya menjadi tokoh yang bisa mempertahankan harkatnya sebagai manusia karena meskipun tokoh 
Rambun bisa menjadi raja dengan mengalahkan tokoh jahat (seorang raja) yang menculik dan memenjarakan ibunya, Rambun tak berniat menjadi raja. Dia lebih memilih hidup damai dengan ibunya dan tetap berjuang melawan kejahatan.

\section{Relevansi Persoalan Anak dalam Mitos dengan Realitas Mutakhir di Indonesia}

Sastra tradisional, termasuk mitos, biasanya dikonsumsikan kepada anak-anak dengan harapan mitos-mitos itu dapat menjadi media pembelajaran agar patuh kepada orang tua. Karena, jika tidak mematuhi perintah orang tua, maka anak-anak akan bisa menjadi tokoh dalam cerita mitos yang dikenai hukuman oleh orang tua. Jika dicermati lebih dalam, sebenarnya cerita mitos tak hanya layak untuk menjadi media pembelajaran bagi anak-anak. Orang tua atau pendidik juga bisa belajar darinya, misalnya mengapa anak yang berpotensi, berkarakter baik, dibesarkan oleh keluarga sendiri namun masih juga mengalami dehumanisasi?

Mencermati mitos-mitos yang dikaji, dapat ditarik suatu kesimpulan bahwa persoalan anak dalam mitos memiliki relevansi dengan persoalan yang saat ini kita temui dalam kehidupan sehari-hari. Negara Indonesia, ditilik dari segi hukum memiliki perhatian yang cukup besar terhadap persoalan anak. Hal itu, setidaknya tercermin dalam sejumlah hukum atau perundang-undangan yang disahkan oleh pemerintah, misalnya Keppres 36 Tahun 1990 mengenai permasalahan yang dihadapi anakanak Indonesia, UU No 4 Tahun 1979 tentang Kesejahteraan Anak, PP No 2 Tahun 1988 tentang Usaha Kesejahteran Anak Bagi Anak Yang Mempunyai Masalah, dan berbagai program yang dilaksanakan oleh Depsos dengan fokus terhadap pelayanan sosial terhadap Anak Balita terlantar, Anak Terlantar, Anak Jalanan, Anak Cacat, Anak Nakal dan Anak-anak yang memiliki masalah kelakuan (perlu perlindungan khusus), dan UU Nomor 23 Tahun 2002 tentang Perlindungan Anak.

Persoalan anak yang ditemui dalam kehidupan masyarakat kita tak terhitung banyaknya. Bahkan, data-data statistik yang dihimpun oleh berbagai lembaga atau institusi, baik itu milik negara maupun swadaya, tak lebih seperti gunung es. Hanya permukaannya saja yang tampak, padahal sebenarnya permasalahannya lebih banyak. Dari persoalan kekerasan pada anak saja, ada empat macam. Menurut Sekretaris Komisi Nasional Perlindungan Anak (Komnas PA) Arist Merdeka Sirait, bentuk kekerasan yang terjadi pada anak antara lain berupa kekerasan seksual, fisik, emosional, dan penelantaran.

Dari kajian yang telah dilakukan, maka ditemui berbagai permasalahan anak yang ditemui dalam mitos-mitos di Indonesia. Permasalahan anak yang terefleksi dalam cerita mitos di Indonesia antara lain kekerasan fisik, kekerasan emosional, dan kekerasan penelantaran. Bentuk kekerasan fisik yang ditemui dalam kajian ini terefleksi dalam cerita mitos Tangkuban Perahu. Ibu Sangkuriang, Dayang Sumbi melakukan pemukulan terhadap anaknya karena marah -setelah sebelumnya sang ibu memarahinya. Cerita mitos Doyan Nada bahkan tak lagi sekedar memukul, tapi berkali-kali diceritakan berupaya menghilangkan nyawa Doyan Nada. Perilaku tokoh ayah Doyan Nada itu dipicu karena perasaan malu terhadap anaknya yang banyak makan

Kekerasan emosional mungkin adalah bentuk persoalan anak yang paling banyak ditemui dalam mitos-mitos di Indonesia. Hampir semua cerita mitos di Indonesia merefleksikan kekerasan ini. Bentuk kekerasan emosional yang ditemui adalah adanya tokoh orang tua yang memarahi anaknya atas kesalahan yang telah dilakukan oleh tokoh anak. Simak misalnya, bagaimana tokoh ayah dalam cerita mitos Asal Mula Pohon Sagu dan Pohon Palem yang sangat tersinggung dengan perilaku tokoh ibu yang menyusul ke lahan, untuk melihat apakah suaminya bekerja atau tidak. Tokoh ayah diceritakan marah luar biasa kepada sang isteri di depan anaknya.

Kekerasan penelantaran terhadap anak, misalnya, terefleksi dalam cerita mitos Padi Muda dan Munculnya Burung Kowa. Dalam 
cerita mitos Padi Muda, tokoh ibu bisa dikatakan menelantarkan hak anaknya untuk memperoleh makanan karena saking asyiknya dengan pekerjaan yang dilakukannya. Sedangkan dalam cerita mitos Munculnya Burung Kowa, tokoh kakak sebagai pengganti orang tua dalam cerita itu juga melakukan penelantaran kepada dua adiknya, Mau dan Bete, yang telah diamanahkan oleh orang tua mereka untuk diasuh. Sedangkan kekerasan seksual, tidak ditemui dalam mitos-mitos yang dikaji.

Persoalan anak dalam mitos-mitos yang dikaji itu memiliki relevansi dengan persoalan anak yang ditemui di masyarakat Indonesia saat ini. Dalam persoalan penelantaran anak, misalnya, Deputi Bidang Perlindungan hak-hak Anak Kementrian Pemberdayaan Perempuan, TB Rachmat Sentika menyatakan bahwa di tahun 2004, jumlah balita penderita gizi buruk di Indonesia adalah 2,3 juta, sedangkan rata-rata lama sekolah anak perempuan 4,7 th dan laki-laki 5,1. (www.gizi.net).

Contoh kasus kekerasan fisik banyak ditemui dalam masyarakat riil. Menurut Komisi Perlindungan Anak Indonesia (KPAID) Kepulauan Riau, permasalahan anak mengalami peningkatan (5 Juli 2007), antara lain: persoalan menyangkut hak asuh, rebutan anak (www.batampos.com). Di Jawa Timur, data dari TESA 129 menunjukkan bahwa hingga Mei 2007, telah terjadi 194 kasus kekerasan terhadap anak. Pelaku kekerasan paling besar (139) justru dilakukan oleh orang terdekat korban (guru, pacar, teman, orng tua), 44 tindak kekerasan dilakukan oleh orang tak dikenal, dan 11 di antaranya dilakukan oleh publik (rumah sakit, aparat penegak hukum) (www.d-info.jatim-go.id).

Belajar dari kasus kekerasan yang berhasil dihimpun TESA 129 di Surabaya, ternyata penyebab atau pelaku kekerasan kebanyakan dilakukan oleh orang-orang terdekat. Hal ini juga terjadi dalam mitos-mitos di indonesia. Tokoh orang tua, dalam mitos yang dikaji, adalah tokoh yang paling banyak memberikan hukuman dan melakukan kekerasan verbal kepada tokoh anak.

Selain itu, Komnas PA sebagai lembaga perlindungan Anak yang secara de facto didukung masyarakat, sepanjang tahun 2006 telah menerima pengaduan dan mencatat berbagai derita anak-anak yang terjadi di sekitar kita. Jumlah anak korban kekerasan di Jabodetabek yang dilaporkan dan ditangani Komnas PA, jumlahnya meningkat dari 481 kasus pada 2004 menjadi 736 kasus pada tahun 2005, dan meningkat lagi menjadi 1.124 kasus pada 2006. Sementara itu, jumlah kekerasan terhadap anak secara nasional diperkirakan mencapai 72 ribu kasus (www.republika.co.id)

Kekerasan verbal mungkin adalah bentuk kekerasan yang tidak begitu mudah untuk didata. Mengapa? Karena bentuk kekerasan inilah yang paling banyak ditemui di dalam masyarakat, dan mungkin dinilai sebagai bentuk kelumrahan yang biasa dilakukan oleh orang tua. Tindakan mengancam anak untuk melakukan perintah orang tua atau mendapat hukuman atau dimarahi jika tak melakukan perintah, tindakan mengecam, tindakan bullying adalah bentuk-bentuk kekerasan verbal yang akan banyak ditemui dalam masyarakat kita. Kekerasan verbal inilah yang juga paling banyak ditemui dalam mitos-mitos yang dikaji.

Permasalahan yang dialami oleh anakanak Indonesia disebabkan oleh beberapa akar permasalahan yang cukup kompleks, antara lain: (1) ekonomi atau kemiskinan, (2) politik: belum optimalnya pelaksanaan perundangan dan peran instansi pemerintahan terkait yang mengurusi persoalan anak, (3) sosial: minimnya ruang anak di tengah-tengah publik dan minimnya layanan publik yang menjadi fasilitator dalam pendampingan permasalahan anak, dan (4) budaya yang menempatkan anak sebagai objek kekuasaan atau adanya dominasi dari orang-orang dewasa, gaya hidup yang hedonis dan konsumtif. Sedangkan permasalahan anak yang terjadi dalam mitosmitos di Indonesia umumnya disebabkan oleh bentuk-bentuk pengasuhan anak yang menempatkan anak sebagai objek kekuasaan dan menempatkan orang tua sebagai penguasa 
yang berhak untuk menentukan segala sesuatunya bagi si anak.

Terkait dengan persoalan anak yang ditemui di dalam kehidupan sehari-hari, ada beberapa cara yang dapat dilakukan untuk menanggulanginya. Misalnya, dengan meningkatkan kesadaran dan mengoptimalkan peran orang tua, keluarga, sekolah dan masyarakat sebagai mitra, pendamping, dan teman/sahabat hidup anak. Anak perlu diposisikan sebagai manusia yang juga memiliki hak yang sama dengan orang dewasa. Anak-anak hanya perlu didampingi dan dipersiapkan untuk menjalani kehidupan. Selain itu, pola-pola pengasuhan anak yang cenderung menempatkan orang dewasa sebagai "penguasa" perlu diubah menjadi pola yang lebih demokratis dan eklektik (pemberian reward dan punishment yang proporsional, dengan cara-cara yang kreatif dan tidak mematikan kreativitas atau membunuh potensi dan karakter anak). Sosialisasi peran dan peningkatan kuantitas dan kualitas layanan publik untuk anak, seperti TESA 129 (pilot profect TESA 129 ada di empat kota di Indonesia: Jakarta, Makasar, Aceh, dan Surabaya) serta pengadaan dan pelayanan hotline service dari KPA di tiap daerah.

\section{PENUTUP}

\section{Kesimpulan}

Dari penelitian terhadap upaya membongkar kesalahan pola asuh anak dalam mitos-mitos di Indonesia, dapat disimpulkan hal-hal sebagai berikut.

(1) Struktur mitos di Indonesia memiliki karakteristik: peran tokoh orang tua yang minim dalam mengasuh anak meskipun tokoh anak memiliki karakter dan potensi yang cukup bagus. Selain itu, model punishment cenderung lebih banyak diberikan daripada reward atau penghargaan kepada anak.

(2) Model pengasuhan anak yang ada dalam cerita mitos di Indonesia sebagian besar menunjukkan pola-pola pengasuhan anak yang kurang ideal karena bersifat searah. Pola pengasuhan anak yang dimaksud adalah pola indulgent, neglectful, dan otoriter.

(3) Tokoh anak-anak memiliki karakter yang positif, berpotensi, dan ada dalam asuhan keluarga terdekat. Namun, peran orang tua yang masih minim dalam kehidupan anak bisa mengakibatkan timbulnya masalah. Pola pengasuhan yang cenderung banyak menggunakan hukuman, sedikit reward akan membuat pola pengasuhan cenderung menempatkan orang tua lebih banyak tampil sebagai penguasa daripada sebagai teman/pendamping anak.

(4) Mitos-mitos yang dikaji memiliki relevansi dengan persoalan anak yang ditemui dalam realitas kehidupan sehari-hari. Persoalan dalam mitos-mitos yang juga ditemukan dalam realitas itu antara lain kekerasan fisik, verbal, dan penelantaran terhadap hak anak.

\section{Saran}

Penelitian ini menunjukkan bahwa ada ada semacam pola pengasuhan anak yang tidak baik atau tidak tepat, yang ditemukan dalam mitos-mitos yang dikaji. Namun, ini bukan berarti bahwa tidak ada contoh pola pengasuhan anak yang bisa dijadikan model untuk mengasuh anak. Untuk itu, perlu ditelilti polapola pengasuhan anak yang positif, yang bisa dipelajari dalam mitos-mitos di Indonesia sebagai bahan pengembangan model pengasuhan bagi anak.

\section{DAFTAR PUSTAKA}

Ahimsa-Putra, Heddy Shri. 1999. Strukturalisme Levi-Strauss: Mitos dan Karya Sastra. Yogyakarta: Galang Press.

Ahimsa-Putra, Heddy Shri. 1998. "LeviStrauss, Orang-orang PKI, Nalar Jawa, dan Sosok Umar Kayam: Telaah Struktural-Hermeneutik Dongeng Etnografis Umar Kayam" dalam Umar kayam dalam Jaring Semiotik (Editor: Aprinus Salam). Yogyakarta: Pustaka Pelajar. 
Endraswara, Suwardi. 2003. Metodologi Penelitian Sastra: Epistimologi Model, Teori, dan Aplikasi. Yogyakarta: Pustaka Widyatama

Junus, Umar. 1981. Mitos dan Komunikasi. Jakarta: Sinar Harapan.

Kompas. 2006. "Televisi: Tontonan Rakyat Bernama Infotainment" dalam Kompas edisi Minggu, 22 Januari 2006. Jakarta: Kompas.

Lukens, Rebecca J. 2003. A Critical Handbook of Children'Samosir Literature. New York: Longman.
Nurgiyantoro, Burhan. 2005. Sastra Anak: Pengantar Pemahaman Dunia Anak. Yogyakarta: Gadjah Mada University Press.

Rahmat, Jamaal Abdul. 2005. Tahapan MendidikAnak. Bandung: IBS.

Saifuddin, Achmad Feyani. 2005. Antropologi Kontemporer: Suatu Pengantar Kritis Mengenai Paradigma. Jakarta: Prenada Media.

Tarigan, Henry Guntur. 1995. Dasar-dasar Psikosastra. Bandung: Angkasa. 